\title{
PROJEKT GRADSKE KNJIŽNICE VUKOVAR - EKOKNJIŽNICA: ZA PRIJATELJSTVO S PRIRODOM
}

\author{
THE PROJECT OF THE VUKOVAR PUBLIC LIBRARY - \\ ECO-LIBRARY: FOR THE FRIENDSHIP WITH NATURE
}

\author{
Marija Bugarski \\ Gradska knjižnica Vukovar \\ marija.bugarski@gkvu.hr \\ Vlatka Surma Szabo \\ Gradska knjižnica Vukovar \\ vlatka.surma.szabo@gkvu.hr
}

\author{
$\mathrm{UDK} / \mathrm{UDC}$ \\ 027.3:502/504(497.5 Vukovar) \\ Stručni rad / Professional paper \\ Prihvaćeno / Accepted: 5.5. 2017.
}

\section{Sažetak}

Gradska knjižnica Vukovar s projektom „Ekoknjižnica: za prijateljstvo s prirodom“ pobijedila je na natječaju „Moja zelena zona“ Zagrebačke banke i osigurala sredstva za uređenje dvorišta u sklopu knjižnice Ogranka Sotin. Pobjedom na natječaju došlo je do orijentacije cjelokupnog poslovanja na ekologiju, održivi razvoj i očuvanje planeta Zemlje. U radu su predstavljene radionice, predavanja, promocije knjiga, predstave, sajam knjiga „LikeBook3 - Zeleno srce grada“ te suradnje sa školama, vrtićima i udrugama s ciljem promocije važnosti očuvanja planeta Zemlje i podizanja svijesti o važnosti ekologije i održivog razvoja.

Ključne riječi: ekoknjižnica, ekološki programi, održivi razvoj, ekološke radionice

Vjesnik bibliotekara Hrvatske 60, 2-3(2017), 295-303

ISSN 0507-1925

(C) VBH 2017. 


\section{Summary}

The project of the Vukovar Public Library "Eco-library: for the friendship with nature", started in 2013, was the winner of the Zagrebačka Bank's competition "My Green Zone" which provided the funds for arranging and decorating the yard of the library branch Sotin. After winning this competition, the whole library management and activities became even more orientated on ecology, sustainable development, and preserving the Planet Earth. This paper presents the workshops, lectures, book promotions, performances, Book Fair: "LikeBook3 - Green Heart of the Town", cooperation with schools, kindergartens, and associations which aim to promote the importance of preserving the Planet Earth and raising the awareness of the importance of ecology and sustainable development.

Keywords: eco-library, environmental programs, sustainable development, ecology workshops

\section{Uvod}

Temi očuvanja okoliša posvećuje se znatna pozornost u različitim područjima, od ekonomskog i političkog do akademskog, o čemu svjedoči i Svjetski skup Ujedinjenih naroda na kojem su se okupili predstavnici vladinih i nevladinih sektora, privatnog poduzetništva, civilnog društva i znanstvene zajednice 191 države. Cilj tog skupa bio je ojačati globalnu obvezu prema održivom razvoju, uvažavajući tehnološki napredak i nove izazove ,,svjetskog gospodarskog poretka“.

Knjižnice su također pronašle način na koji se mogu uključiti te svojom djelatnošću doprinijeti očuvanju okoliša. Binks ističe dva područja na kojima knjižnice mogu djelovati. Prvo područje orijentirano je na zgrade knjižnica, dok je drugo usmjereno prema zajednici unutar koje knjižnice djeluju.

U prvom području knjižničari kroz vlastitu edukaciju i uvođenje promjena $u$ knjižnice utječu na stvaranje zelenih knjižnica. Neke od aktivnosti koje provode su i ,vrednovanje uredskog materijala i zamjena istog ,zelenijim“ alternativama, uključivanje zelenih materijala za zgrade prilikom renoviranja ili izgradnje novih zgrada, nabava elektroničke opreme koja ima certifikat Energy Star, instaliranje termostata koji neće raditi kada ljudi nisu prisutni u prostoriji, zamjena običnih žarulja fluorescentnima, upotreba šalica i tanjura za višekratnu upotrebu, sadnja cvijeća i biljaka ispred zgrade i pokretanje bibliobusa na biodizel“". ${ }^{2}$ Nadalje,

\footnotetext{
1 Izvješće o UN-ovu Svjetskom skupu na vrhu o održivom razvoju u Johannesburgu. [citirano: 2016-01-11]. Dostupno na http://www.mvep.hr/.

2 Usp. Binks, Lisa; Emily Braithwaite; Lisa Hogarth; Andrew Logan; Stephanie Wilson. Tomorrow's green public library // Australian Library Journal 63, 4(2014), str. 302. [citirano: 201511-27]. Dostupno na http://ebscohost.com.
} 
knjižničari mogu doprinijeti stvaranju zelenih knjižnica ako postave koševe za odlaganje papira na javna mjesta gdje je velika protočnost ljudi i istaknu njihovu namjenu, koriste LCD-monitore, izbjegavaju screensavere te gase računala kada ih ne koriste ${ }^{3}$, ispisuju na zahtjev i pritom koriste široke margine i mali font kako bi uštedjeli na papiru, na posao dolaze pješice, biciklom ili javnim prijevozom ${ }^{4}$ te nabavljaju online inačice enciklopedija umjesto tiskanih. ${ }^{5}$ Praćenjem energetske učinkovitosti zgrade kroz godine te na temelju dobivenih podataka moguće je provoditi adaptacije na zgradi ${ }^{6}$ kao što su postavljanje solarnih panela na krov zgrade knjižnice te izgradnja zgrada koje će koristiti prirodno svijetlo umjesto žarulja. ${ }^{7}$ Edukacija knjižničara izuzetno je važna, pa je Sveučilište Duke organiziralo radionicu Leading for Sustainability na kojoj su sudjelovali djelatnici Duke University Medical Center Library te su po završetku radionice započeli s projektom prelaska s papirnih formata na elektroničke materijale, a dosad su projekt po pitanju časopisa odradili $100 \%$, a po pitanju knjiga $75 \%{ }^{8}$ Aulisio navodi radionice Education for Sustainable Development (ESD) i Enviromental Education (EE) na kojima bi trebali sudjelovati knjižničari jer im se nudi prilika za upoznavanje ljudi koji su također zainteresirani za održivost, otvara im se mogućnost suradnje i pokretanja zajedničkih projekata. ${ }^{9}$

Drugo područje u kojem knjižnice mogu djelovati jest područje edukacije korisnika, gdje one mogu poslužiti kao primjer dobre prakse i potaknuti korisnike na promjene. Neke od aktivnosti koje knjižničari mogu provoditi su i "osnivanje ekološkog čitateljskog kluba, izložba knjiga i DVD-a na temu održivosti te organiziranje filmskog festivala na istu temu, smanjenje kopiranja i poticanje korištenja digitalnih medija, realizacija programa s temom održivosti, suradnja s lokalnim udrugama za očuvanje okoliša i pokretanje programa recikliranja te promocija

3 Usp. Neale, Jane C.Go Green! // Library Journal 133, 2 (2008), str. 46. [citirano: 2015-10-17]. Dostupno na http://ebscohost.com/.

4 Usp. Peterson, Richard A.; Megan von Isenburg; Barbara Dietsch; Dawne Lucas. Going green: one library's journey toward sustainability. // Journal of Hospital Librarianship 14, 1(2014), str. 19. [citirano: 2015-10-29]. Dostupno na http://ebscohost.com/.

5 Usp. Blaine, Amy S. Creating a lean, green, library machine: easy eco-friendly habits for your library. // Library Media Connection 28, 4(2010), str. 25. [citirano: 2015-10-28]. Dostupno na http://ebscohost.com.

6 Usp. Hauser, Emilie. Energy conservation and sustainability steps at te Kingston Library. // Journal of the Library Administration \& Management Section 11, 1(2014), str. 6. [citirano: 201510-24]. Dostupno na http://ebscohost.com/.

7 Usp. Clark, Amanda C. R. Greening the library: easy sustainability. // Alki 30, 3(2014), str. 22. [citirano: 2015-11-11]. Dostupno na http://ebscohost.com/.

8 Usp. Peterson, Richard A.; Megan von Isenburg; Barbara Dietsch; Dawne Lucas. Nav. dj., str. 16.

9 Usp. Aulisio, George J. Green libraries are more than just buildings. // Electronic Green Journal, 35, 1(2013), Str. 5. [citirano: 2015-11-03]. Dostupno na http://ebscohost.com. 
svih aktivnosti koje su orijentirane prema očuvanju okoliša“.${ }^{10}$ Izvrstan primjer edukacije korisnika dolazi iz Hrvatske, gdje je Društvo bibliotekara Istre 2011. godine započelo projekt ,Zelena knjižnica“ putem kojeg je kroz djelovanje knjižnica i knjižničarskih društava željelo poučiti javnost i proširiti svijest o održivom razvoju i nužnosti zaštite okoliša. ${ }^{11}$ U sklopu projekta od ožujka 2011. do rujna 2012. godine održana su 32 stručna predavanja, 21 kreativna radionica, 1 tribina te 17 projekcija poučno-dokumentarnih filmova, dok putem svoje mrežne stranice i Facebook-profila nude mnoge zanimljive sadržaje. ${ }^{2} \mathrm{Cilj}$ je projekta kroz portal „Zelena knjižnica“, projekcije dokumentarnih filmova, stručna predavanja, tribine i promocije knjiga educirati javnost i širiti svijest o održivom društvu i nužnosti zaštite okoliša. ${ }^{13}$ Također je pri Hrvatskom knjižničarskom društvu 2014. godine osnovana Radna grupa za Zelene knjižnice čiji je smisao uspostavljanje mreže knjižnica koje bi se uključile u već postojeći obrazac projekta „Zelena knjižnica“ s ciljem edukacije javnosti i podizanja svijesti o održivom društvu i nužnosti zaštite okoliša kroz knjižnice i knjižničarska društva. Osim tog segmenta, radna grupa bavi se i pitanjima energetske učinkovitosti u knjižnicama. ${ }^{14}$

Osim promjena koje vrše na zgradama knjižnice i programa koje provode unutar zajednice u kojoj djeluju, izuzetno je važna i promocija aktivnosti na lokalnoj i državnoj razini. U organizaciji Ekonomskog Fakulteta u Osijeku održan je okrugli stol „Kreiranja knjižnice zelene boje“ na kojem su predstavnici ekoknjižnica i zelenih knjižnica iznijeli svoja iskustva širenja svijesti o održivom razvoju i nužnosti zaštite okoliša. ${ }^{15}$

Primjeri iz literature pokazuju da se knjižnice i ekologija povezuju na dva područja. Prvo je područje gradnja ,zelenih zgrada“, a drugo edukacija korisnika putem programa, predavanja, posjeta i kvalitetnih tiskanih zbirki i online materijala na temu ekologije.

\section{Ekološki programi Gradske knjižnice Vukovar}

Projekt Gradske knjižnice Vukovar, Ogranak Sotin „Ekoknjižnica: za prijateljstvo s prirodom“ pobijedio je na natječaju Moja zelena zona Zagrebačke

10 Usp. Binks, Lisa; Emily Braithwaite; Lisa Hogarth; Andrew Logan; Stephanie Wilson. Nav. dj., str. 302.

${ }_{11}$ Usp. Kraljević, Ivan. Zelena knjižnica: projekt Društva bibliotekara Istre. // Vjesnik bibliotekara Hrvatske 56, 3(2013), str. 199.

12 Isto, str. 201.

13 Zelena knjižnica. [citirano: 2017-05-02]. Dostupno na http://zk.dbi.hr/?p=103.

14 HKD. Radna grupa za Zelene knjižnice. [citirano: 2017-05-02]. Dostupno na http://www. hkdrustvo.hr/hr/strucna_tijela/50/.

15 Kreiranje knjižnica zelene boje. [citirano: 2016-09-27]. Dostupno na http://www.efos.unios. $\mathrm{hr} /$ kreativna-riznica/kreiranje-knjiznica-zelene-boje/. 
banke i osvojio sredstva za uređenje dvorišta knjižnice. Predviđeno je da će se dvorište preurediti u interaktivnu učionicu na otvorenom u kojoj će se nalaziti plastenik, povrtne gredice i dječje igralište na kojem će djeca moći uzgajati voće i povrće jer, kako ističe Cindrić, sadnjom bilja kod djece stvaramo pozitivan odnos prema živim bićima, a sudjelovanjem u različitim ekološkim akcijama djeca osvješćuju svoj ekološki odgoj. ${ }^{16}$ Cilj projekta bilo je razvijanje ekološke svijesti, pozitivnih stavova prema okolišu i osjetljivosti za ekologiju kod djece i odraslih. Za vrijeme trajanja uređenja dvorišta Ogranka Sotin, Gradska knjižnica Vukovar (u nastavku teksta: Knjižnica), u sklopu koje djeluju Dječji odjel, Odjel za odrasle, Studijski odjel i Američki kutak, organizirala je aktivnosti orijentirane prema ekologiji koje su provođene u sklopu projekta, a bit će predstavljene u nastavku rada.

\subsection{Programi na Odjelu za odrasle}

Binks ${ }^{17}$ i suradnici slažu se s Griebel ${ }^{18}$ u pogledu dobre pozicije koju knjižnice zauzimaju u zajednici unutar koje djeluju, jer mogu organizirati programe putem kojih će educirati korisnike. U suradnji s Europskim domom Vukovar u Knjižnici je održan okrugli stol „Priroda kao saveznik“ na kojoj je ekolog Vjeran Piršić, predsjednika udruge Eko Kvarner, istaknuo da je najbolja prilika za razvitak Vukovara ekološka poljoprivreda s plasmanom robe u turističke svrhe. ${ }^{19}$ Prof. dr. sc. Dražen Šimleša, stručnjak za globalizaciju i održivi razvoj, održao je predavanje o važnosti suradnje i uključenosti ekonomije i politike za postizanje konkretnih rezultata u pogledu očuvanja okoliša. U suradnji s Udrugom Vukovarci dobre volje održana su predavanja „Zeleno za zdravlje“ i „Večer meda“, dok je u suradnji s Gimnazijom, Ekonomskom i Tehničkom školom proveden projekt „Eko pitanja s odgovorima“ putem kojeg je istražena plodnost tla grada Vukovara i okolice, a rezultati su predstavljeni na istoimenom predavanju održanom u Knjižnici.

Spojem predavanja različite tematike orijentiranih prema održivom razvoju te predstavljanjem aktivnosti udruga Knjižnica je na jednom mjestu objedinila širok spektar ljudi od kojih svatko djeluje u svome području, a svima je zajed-

\footnotetext{
16 Cindrić, Anita. Ekološka promišljanja u likovnim aktivnostima djece predškolskog uzrasta. // Ekologija: korak bliže djetetu: zbornik radova stručno-znanstvenog skupa. Rijeka, 21.-23 listopada 1999. Rijeka: Adamić, 2000. Str. 59.

17 Usp. Binks, Lisa; Emily Braithwaite; Lisa Hogarth; Andrew Logan; Stephanie Wilson. Nav. dj., str. 302.

18 Usp. Griebel, Rosemary. How green is my library. // Feliciter 58, 1(2012), str. 2. [citirano: 2015-11-09]. Dostupno na http://ebscohost.com/.

19 Usp. Priroda kao saveznik u Gradskoj knjižnici Vukovar. [citirano: 2016-02-08]. Dostupno na http://www.gkvu.hr/index.php/vijesti/180-odrzivost-modni-trend-ili-uvjet-za-prezivljavanje-.
} 
nički jedan cilj - očuvanje okoliša. Kroz programe su povezane škole i udruge te je omogućena razmjena iskustava, dok su oni doprinijeli zelenoj misiji Knjižnice koja je pokretanjem projekta „Ekoknjižnica: za prijateljstvo s prirodom“ postala sjecište puteva obrazovnih ustanova i neprofitnih udruga.

\subsection{Programi na Dječjem odjelu}

U sklopu projekta „Ekoknjižnica: za prijateljstvo s prirodom“ velik naglasak stavljen je na organiziranje i realizaciju programa namijenjenih djeci s ciljem razvijanja osjećaja i svijesti prema okolišu, povećavanja znanja o ekološkim problemima, njegovanja pozitivnih stavova prema okolišu, razvijanja ekoloških vještina i stvaranja prilika za aktivno sudjelovanje i rješavanje problema okoliša (Lane i Rossow, 1993:226-228). ${ }^{20}$

Ostvarena je suradnja s vrtićima i osnovnim školama s područja grada Vukovara, ali i okolnih mjesta. Djeca su prisustvovala promociji slikovnica Marice Milčec i Darija Kukića „Spasimo zemlju“, „Zatvori vodu“, „Nije smeće sve za vreće“, „Zraka trebam, hitno!“ i „U tlu čistu imamo glistu“. Također su posjetila Knjižnicu kako bi prisustvovala predstavi „Alergična planeta Zemlja“, obradi lektire „Pismo iz Zelengrada“ Nevenke Videk, kreativnoj radionici „Veseli kukci“ te edukativnim radionicama "Močvara: priča o životu jednog vretenca“ nakon koje su pod mikroskopom gledali kap močvarne vode i, „Suma i njezini stanovnici“ na kojoj je profesorica biologije pred njima secirala glistu.

Osim gore navedenih programa, organizirane su dvije tjedne radionice na koje su djeca dolazila dobrovoljno - „Ekolaboratorij“ i „Čuvari okoliša“. Na radionici „Ekolaboratorij“ djeca su u kontroliranim uvjetima, pod nadzorom knjižničarke, izvodila eksperimente i razgovarala o ekologiji. Radionica je bila utemeljena na ideji centra učenja koji bi trebao omogućiti konkretno istraživanje, rješavanje problema, igru te poštivanje dječjih sposobnosti i interesa. Prilikom realizacije radionice pravila su bila jasno definirana, a materijali su stajali djeci na raspolaganju te ih se poticalo da međusobno razgovaraju, dijele ideje i zajednički rješavaju probleme te dolaze do zaključaka. ${ }^{21}$ Radionica „Čuvari okoliša“ bila je kreativno-edukativnog karaktera te su djeca od materijala namijenjenih za otpad stvarala nove predmete i ujedno učila o važnosti recikliranja.

20 Lane, J. F.; C. E. Rossow. Sources and ideas for special projects. // Environmental education / Wilke, R. J. (ur). New York : Kraus International Publications, 1993. citirano prema: Uzelac, Vinka; Irena Starčević. Djeca i okoliš. Rijeka: Adamić, 1999. Str. 11-12.

${ }_{21}$ Usp. Petrović-Sočo, Biserka. Neke suvremene stručno-metodičke osnove ekološkog odgoja u predškolskoj ustanovi. // Ekologija: korak bliže djetetu: zbornik radova stručno-znanstvenog skupa. Rijeka, 21.-23. listopada 1999. Rijeka: Adamić, 2000. Str. 45. 
Jedan od ciljeva projekta bila je edukacija djece o važnosti očuvanja okoliša. Programi koji su provedeni u suradnji s vrtićima i školama bili su prilagođeni različitim uzrastima djece, a svi su imali jedan zajednički nazivnik: očuvanje planeta Zemlje i buđenje svijesti kod djece o tome što ona svakodnevnim postupcima mogu učiniti kako bi doprinijela očuvanju okoliša.

\subsection{Sajam knjiga LikeBook3 - Zeleno srce grada i manifestacija „Noć knjige“6}

Gradska knjižnica Vukovar treću godinu zaredom uspješno je organizirala sajam knjige LikeBook. Tema trećeg po redu sajma knjige bila je povezana s projektom ekoknjižnice i nosila je naziv „Zeleno srce grada“, dok su sve aktivnosti bile usmjerene na očuvanje okoliša i promicanje zdravog načina života. Osim „Tržnice knjiga“ na kojoj se prodavalo više od 5000 naslova nakladničkih kuća iz Hrvatske, Srbije i Bosne i Hercegovine, posjetitelji sajma mogli su degustirati različite makrobiotičke namaze i napitke, dok su učenici Gimnazije i Tehničke škole Vukovar predstavili rezultate istraživanja zajedničkog projekta „Primjena prirodnih i umjetnih gnojiva u obogaćivanju tla na području grada Vukovara i okolice te utjecaj na okoliš".

Za djecu su organizirane ekološke kreativne radionice te tematska iPad-igraonica na engleskom jeziku usmjerena prema očuvanju okoliša. Djeca su mogla pogledati tarantule koje je predstavila Udruga za uzgoj i zaštitu životinja „Feniks“ te prisustvovati promociji slikovnica „Koprivkov svijet“.

Središnja aktivnost sajma knjiga bila je sadnja cvijeća, začinskog bilja i trajnica kojima je formiran glagoljični logo Gradske knjižnice Vukovar koji čini središnji dio čitaonice na otvorenom, a koja je trajno poklonjena gradu Vukovaru i svim njegovim stanovnicima.

Manifestacija „Noć knjige“ također je organizirana u ekološkom duhu jer su sve aktivnosti imale jedan zajednički nazivnik - ekološki. Svoj rad predstavile su udruge s područja grada Vukovara koje se bave ekološkim uzgojem voća i povrća. Svi posjetitelji mogli su pogledati hotel za kukce te poslušati predavanje učenika Gimnazije na temu „Uloga kukaca u prirodi““.

Za najmlađe korisnike, na Dječjem odjelu organizirana je igra „Potraga za kukcima u knjigama" te kreativna radionica izrade krila i ticala. U okviru Američkog kutka posjetiteljima su na raspolaganju bili iPad-uređaji s brojim igricama i edukativnim sadržajima na temu ekologije.

Noć knjige pokazala se kao izvrsna prilika za promociju ekologije i održivog razvoja te upoznavanje korisnika s projektom „Ekoknjižnica: za prijateljstvo s prirodom". 


\section{Zaključak}

Knjižnice, osim ponude literature o ekologiji, mogu biti predvodnici u promociji edukacije o zaštiti okoliša organiziranjem različitih predavanja, promocija knjiga i radionica namijenih svim dobnim skupinama korisnika. Angažiranost djelatnika izuzetno je važna jer oni mogu biti pokretači promjena te svojim ponašanjem pružiti primjer korisnicima i zajednici. Gradska knjižnica Vukovar projektom „Ekoknjižnica: za prijateljstvo s prirodom“, unutar kojeg su realizirani mnogobrojni programi namijenjeni različitim skupinama korisnika od djece do korisnika treće životne dobi, ostvarila je svoju zelenu misiju. Organiziranjem edukativnih i kreativnih radionica, predstava, predavanja istaknutih stručnjaka s područja ekologije i održivog razvoja te suradnjom s udrugama, vrtićima, osnovnim i srednjim školama, omogućila je razmjenu ideju te postala središte koje pruža sve potrebne informacije o ekologiji i educira korisnike.

\section{LITERATURA}

Aulisio, George J. Green libraries are more than just buildings. // Electronic Green Journal, 35, 1(2013), str. 5. [citirano: 2015-11-03]. Dostupno na http://ebscohost.com

Binks, Lisa; Emily Braithwaite; Lisa Hogarth; Andrew Logan; Stephanie Wilson. Tomorrow's green public library. // Australian Library Journal 63, 4(2014), 301-312. [citirano: 2015-11-27]. Dostupno na http://ebscohost.com

Blaine, Amy S. Creating a lean, green, library machine: easy eco-friendly habits for your library. // Library Media Connection 28, 4(2010), 24-26. [citirano: 2015-1128]. Dostupno na http://ebscohost.com

Cindrić, Anita. Ekološka promišljanja u likovnim aktivnostima djece predškolskog uzrasta. // Ekologija: korak bliže djetetu: zbornik radova stručno znanstvenog skupa. Rijeka, 21.-23. listopada 1999. Rijeka: Adamić, 2000. Str. 55-61.

Clark, Amanda C. R. Greening the library: easy sustainability. // Alki 30, 3(2014), $22-$ 24. [citirano: 2015-11-11]. Dostupno na http://ebscohost.com

Griebel, Rosemary. How green is my library. // Feliciter 58, 1(2012), 3-11. [citirano: 2015-11-09]. Dostupno na http://ebscohost.com

Hauser, Emilie. Energy conservation and sustainability steps at the Kingston Library. // Journal of the Library Administration \& Management Section 11, 1(2014), 6-22. [citirano: 2015-10-24]. Dostupno na http://ebscohost.com

HKD. Radna grupa za Zelene knjižnice. [citirano: 2017-02-05]. Dostupno na http:// www.hkdrustvo.hr/hr/strucna_tijela/50/ 
Izvješće Ujedinjenih naroda o Svjetskom skupu na vrhu o održivom razvoju u Johannesburgu. [citirano: 2016-01-11]. Dostupno na http://www.mvep.hr

Kraljević, Ivan. Zelena knjižnica: projekt Društva bibliotekara Istre. // Vjesnik bibliotekara Hrvatske 56, 3(2013), str. 199-204.

Lane, J.F.; C. E. Rossow. Sources and ideas for special projects. // Environmental education / Wilke, R.J.(ur) . New York : Kraus International Publications, 1993.Str. 225-261.

Neale, Jane C. Go green! // Library Journal 133, 2 (2008), 46-46. [citirano: 2015-1017]. Dostupno na http://ebscohost.com

Peterson, Richard A.; Megan von Isenburg; Barbara Dietsch; Dawne Lucas. Going green: one library's journey toward sustainability. // Journal of Hospital Librarianship 14, 1(2014), 14-23. [citirano: 2015-10-29]. Dostupno na http://ebscohost.com

Petrović-Sočo, Biserka. Neke suvremeno stručno-metodičke osnove ekološkog odgoja u predškolskoj ustanovi. // Ekologija: korak bliže djetetu: zbornik radova stručno znanstvenog skupa. Rijeka, 21.-23 listopada 1999. Rijeka : Adamić, 2000. Str. 43-48.

Priroda kao saveznik u Gradskoj knjižnici Vukovar. [citirano: 2016-02-08]. Dostupno na http://www.gkvu.hr/index.php/vijesti/180-odrzivost-modni-trend-ili-uvjet-za-prezivljavanje-

Uzelac, Vinka; Irena Starčević. Djeca i okoliš. Rijeka: Adamić, 1999.

Zelena knjižnica. [citirano: 2017-05-02]. Dostupno na http://zk.dbi.hr/?p=103 